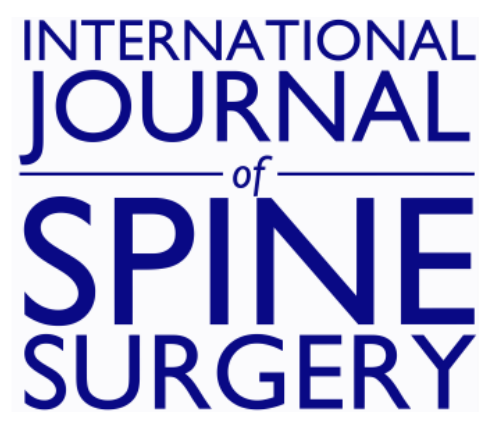

\title{
Chromium and Nickel Concentrations in Subjects with a Stainless Steel Metal-on-Metal Cervical Disc Arthroplasty: Results from a Prospective Longitudinal Study with 7 Years Follow-Up
}

\author{
VANEET SINGH, ANASTASIA K. SKIPOR, ABDULHAFEZ A. SELIM and JOSHUA J. \\ JACOBS
}

Int J Spine Surg 2018, 12 (4) 460-468

doi: https://doi.org/10.14444/5055

http://ijssurgery.com/content/12/4/460

This information is current as of April 25, 2023.

Email Alerts Receive free email-alerts when new articles cite this article. Sign up at: http://ijssurgery.com/alerts 


\title{
Chromium and Nickel Concentrations in Subjects with a Stainless Steel Metal-on-Metal Cervical Disc Arthroplasty: Results from a Prospective Longitudinal Study with 7 Years Follow-Up
}

\author{
VANEET SINGH, MS, MBA, ${ }^{1}$ ANASTASIA K. SKIPOR, MS, ${ }^{2}$ ABDULHAFEZ A. SELIM, MD, PhD, ${ }^{1}$ JOSHUA \\ J. JACOBS, MD ${ }^{2}$ \\ ${ }^{1}$ Medtronic, Inc., Memphis, Tennessee, ${ }^{2}$ Department of Orthopaedic Surgery, Rush University Medical Center, Chicago, Illinois
}

\begin{abstract}
Background: Cervical disc arthroplasty (CDA) has emerged as an alternative to anterior cervical discectomy and fusion for degenerative cervical disc disease. The artificial discs provide intervertebral motion using multicomponent articulation and thus tend to generate particulate debris and soluble metal ions. Limited information is available on the long-term metal concentrations and associated systemic adverse events observed in metal-on-metal CDA. Serum chromium $(\mathrm{Cr})$ and nickel (Ni) concentrations were assessed in patients implanted with ball-in-trough stainless steelbased cervical disc through 7 years.

Methods: A prospective, nonrandomized longitudinal study was conducted that included 25 patients following rigorous exclusion criteria that included no previous permanent metal implants and no professional exposure to metal particles. Blood serum $\mathrm{Cr}$ and $\mathrm{Ni}$ concentrations were assayed preoperatively and at 3, 6, 12, 24, 36, 60, and 84 months postoperatively using high-resolution inductively coupled plasma-mass spectrometry. Longitudinal statistical comparisons were made using the Friedman test with statistical significance at $P<.05$.

Results: Median serum concentrations determined preoperatively and at 3, 6, 12, 24, 36, 60, and 84 months postoperatively were $0.074,0.106,0.132,0.170,0.172,0.274,0.192$, and $0.203 \mathrm{ng} / \mathrm{mL}$ for $\mathrm{Cr}$ and $0.085,0.178,0.222$, $0.175,0.205,0.284,0.181$, and $0.194 \mathrm{ng} / \mathrm{mL}$ for $\mathrm{Ni}$. The serum $\mathrm{Cr}$ concentrations were statistically higher for all postoperative time periods compared to preoperative concentration (Friedman $P<.01$ ), whereas serum $\mathrm{Ni}$ concentration was statistically higher at the 84-month postoperative time period than the preoperative concentration (Friedman $P<.01$ ) and then the concentration at 3, 12, 24, and 60 months postoperatively (Friedman $P<.03$ ).

Conclusions: The $\mathrm{Cr}$ concentrations detected at all postoperative times were statistically higher than preoperative concentrations, whereas $\mathrm{Ni}$ concentration was statistically higher than the preoperative concentration only at 84 months.
\end{abstract}

\section{Research Article}

Keywords: cervical disc, chromium, metal-on-metal, nickel, wear

\section{INTRODUCTION}

Anterior cervical discectomy and fusion (ACDF) is an effective modality to treat cervical degenerative disc disease by decompressing the neural elements and stabilizing the cervical spine. However, cervical disc arthroplasty (CDA) has emerged as an alternative treatment to ACDF for cervical degenerative disc disease with superior clinical outcomes. ${ }^{1,2}$ The CDA has the potential of reducing the incidence of adjacent level degeneration commonly associated with ACDF by preserving motion at the treated level. $^{3-6}$ In addition, CDA mitigates nerve root compression by restoring both intervertebral disc and foraminal height. ${ }^{7}$ Most commonly, the artificial cervical discs provide intervertebral motion using multicomponent articulation. However, the intervertebral articulation of these artificial disc components can generate in vivo wear in the form of particulate debris and soluble metal ions similar to any other large joint articulating implant. The clinical performance of the articulating implants have been observed to be dependent on the host response to the generated particulate debris and metal ions among other factors. ${ }^{8,9}$ Conventional ultra-high-molecular-weight polyethylene (UHMWPE)/metal-bearing couples for large joint 
implants have exibited evidence of limited survivorship with UHMWPE-induced osteolysis and aseptic loosening of the implants. ${ }^{10,11}$ Hard-on-hard bearing surfaces, such as metal-on-metal (MOM), have thus been explored for articulating applications, as the generated wear is expected to be less due to the superior wear properties of certain metallic materials in comparison to conventional UHMWPE. One such MOM cervical artificial disc, PRESTIGE Cervical Disc (Medtronic, Memphis, TN) was approved by the US Food and Drug Administration in July 2007. It is a 2-component ball-in-trough design made out of $316 \mathrm{~L}$ stainless steel material consistent with the specifications of the American Society for Testing and Materials (ASTM F138). In a prospective, randomized, nonblinded clinical study with a total of 541 subjects, the noninferiority in overall success was confirmed for the investigational PRESTIGE disc group $(N=276) .{ }^{12}$ The overall success rates were reported to be $75.0 \%$ and $63.7 \%$ for the investigational and ACDF control groups, respectively, at 84 months. The cervical disc maintained sagittal angular motion through 84 months averaging 6.75 degrees at the treated level at 84 months, while the second surgeries involving adjacent levels were reported to be $4.6 \%$ for the investigational group compared to $11.9 \%$ for the ACDF control group with statistical significance $(P$ $=.008){ }^{12}$ The ball-in-trough articulation provides 4 independent degrees of freedom for the in vivo device mobility. Despite superior wear resistance of MOM articulating implants in comparison to metalon-polyethylene, there have been concerns around the adverse local and systemic effects attributed to the elevated metal concentrations in local and remote sites as observed in association with MOM total hip implants. ${ }^{13,14}$

The potential of particulate debris generation in the PRESTIGE disc was assessed in an in vitro long-term durability and wear test, and the wear patterns were characterized from the retrieved and in vitro tested discs. ${ }^{15}$ In this study, Kurtz et al observed that the in vitro evaluation of the disc represented a more severe wear scenario than would be encountered in vivo. Even though this study provides some insight into the potenial of MOM cervical discs to generate in vivo wear, information about the distribution of wear debris in the bloodstream is still not available. Elevated blood metal concentrations have been associated with adverse local and systemic effects observed in
MOM total hip implants. ${ }^{16}$ Most commonly, MOM articulating devices have been associated with the elevated metal concentrations, but this has also been observed for the non-MOM articulating devices, including metal-on-polyethylene and ceramic-on-polyethylene, because of various mechanical phenomena, including tribocorrosion at modular junction metal interfaces. ${ }^{17,18}$ The longterm clinical implications of elevated metal concentrations are still not well understood and require long-term patient survelliance for metal concentrations and any related adverse events. Previous studies have reported on the long-term cobalt $(\mathrm{Co})$, chromium $(\mathrm{Cr})$, nickel $(\mathrm{Ni})$, and titanium metal concentrations for various articulating large joints ${ }^{17-20}$ and $\mathrm{Cr}$ and $\mathrm{Ni}$ concentrations in pediatric and adult subjects implanted with stainless steelbased nonarticulating posterior spinal instrumention. ${ }^{21-26}$ However, no information is available on the long-term metal concentrations in the articulating stainless steel spinal implants. The metal concentrations reported for stainless steel-based posterior fixation spinal instrumentation provide some indications about the metal concentrations in spinal implants but may not truly represent the metal concentrations resulting from an articulating device, as the fundamental mechanism of wear (and thus the resulting debris and metal serum concentrations) is different between the 2 types of devices. Wear generated by posterior spinal instrumentation is primarily from fretting micromotion accompanied by corrosion ${ }^{27}$ compared with the abrasive wear and microscopic surface fatigue observed in articulating MOM discs. ${ }^{28}$

The objective of the present study was to assess the blood metal concentrations in the subjects implanted with stainless steel-based cervical disc.

\section{METHODS}

A prospective, nonrandomized longitudinal study was conducted that included 25 subjects implanted with the PRESTIGE Cervical Disc System. This study measuring serum metal concentrations was conducted under a US Food and Drug Administration-approved investigational device exemption (G010188) and was a part of the PRESTIGE cervical disc system postapproval study $(N=59)$. The study was approved by the institutional review board of each participating site, and all participants signed an informed consent prior to their inclusion in the study. The subjects in this study were enrolled 
Table 1. Patient demographics.

\begin{tabular}{lc}
\hline Age (y), mean \pm SD & $48.2 \pm 6.4$ \\
Height (in.), mean \pm SD & $67.4 \pm 4.4$ \\
Weight (lbs), mean \pm SD & $180 \pm 35.5$ \\
$\%$ Male & $36 \%$ \\
$\%$ Caucasian & $88 \%$ \\
\hline
\end{tabular}

at 2 investigational sites in the United States and consisted of 9 males and 16 females with an average age at implantation of 48.2 years (range 36.0-58.0 years). Fourteen subjects were treated at C5-C6 and 11 at C6-C7. Subject demographic data are shown in Table 1.

The subjects enrolled in the continued access arm of the trial were screened for eligibility based on the protocol-specified inclusion and exclusion criteria of the trial. The exclusion criteria was specifically expanded for the study of metal concentrations to reduce additional sources of metal exposure and included exclusion for patients:

- With any prior procedure requiring the use of permanent metal implants (ie, stents, joint replacement, and/or dental implants [does not include fillings, crowns, or braces])

- Working in a profession with increased exposure to metal particles (ie, jewelry making, construction, ironworking, metal grinding, welding, etc.).

Blood samples were collected preoperatively and at $3,6,12,24,36,60$, and 84 months postsurgery. Venipuncture using a butterfly needle in triplicate SMonovette (Sarstedt, Nümbrecht, Germany) syringes was used to collect the blood. The first collected vial served to rinse the needle, tubing, and multiadapter and thus was discarded, while second and third vials were used only for the metal concentration analysis. To avoid potential contamination, all the laboratory supplies, including storage tubes, pipette tips, and vessels in contact with the samples, were acid washed prior to their use in the blood collection procedure. The blood samples were left at room temperature to clot before these were centrifuged to separate into serum and cell fraction, and then these serum samples were stored at $-80^{\circ} \mathrm{C}$ until analyzed. To minimize any atmospheric and manual contamination, all the postcollection sample handing was carried out in a class 100 clean room environment. The Rush University Medical Center Trace Metal Analysis Laboratory has used the blood collection procedure adopted in the current
Table 2. Median $\mathrm{Cr}$ and $\mathrm{Ni}$ concentrations in $\mathrm{ng} / \mathrm{mL}$.

\begin{tabular}{lcc}
\hline Time Point & Cr Concentration & Ni Concentration \\
\hline Preoperative & 0.074 & 0.085 \\
3 months & 0.106 & 0.178 \\
6 months & 0.132 & 0.222 \\
12 months & 0.170 & 0.175 \\
24 months & 0.172 & 0.205 \\
36 months & 0.274 & 0.284 \\
60 months & 0.192 & 0.181 \\
84 months & 0.203 & 0.194 \\
\hline
\end{tabular}

${ }_{33}$ study as a standard practice for nearly 2 decades. ${ }^{29-}$

A high-resolution inductively coupled plasmamass spectrometer (Element 2, Thermo-Finnigan MAT, Bremen, Germany) was used to assay serum for $\mathrm{Cr}$ and $\mathrm{Ni}$. The testing was conducted using the method of additions, and the detection limits for $\mathrm{Cr}$ and $\mathrm{Ni}$ in serum were 0.015 and $0.17 \mathrm{ng} / \mathrm{mL}$, respectively. The Rush University Medical Center Trace Metal Analysis Laboratory ensured the accuracy and performance for $\mathrm{Cr}$ and $\mathrm{Ni}$ by analyzing Seronorm Trace Elements Serum L-1 and L-2 (Sero, Billingstad, Norway).

Any concentration values below the detection limit were assigned a value of one-half the detection limit: $0.008 \mathrm{ng} / \mathrm{mL}$ for $\mathrm{Cr}$ and $0.085 \mathrm{ng} / \mathrm{mL}$ for $\mathrm{Ni}$.

\section{STATISTICAL METHODS}

Longitudinal statistical comparisons were made using the Friedman test with statistical significance at $P<.05$.

\section{RESULTS}

Twenty-five subjects were enrolled in the study; however, a few were lost to follow-up until the 84month interval. Two subjects missed their 24-month appointments, whereas 4 subjects missed their 36and 60 -month appointments. In addition, 7 subjects missed their 84-month appointments. This resulted in a sample size of 25 at the preoperative through 12 months, 23 at 24 months, 21 at 36 and 60 months, and 18 at 84 months.

The preoperative median serum $\mathrm{Cr}$ and $\mathrm{Ni}$ concentrations and those at 3, 6, 12, 24, 36, 60, and 84 months postoperation are provided in Table 2. A box plot distribution of serum $\mathrm{Cr}$ and $\mathrm{Ni}$ concentrations is presented in Figures 1 and 2, respectively. Serum Cr concentrations were statistically higher for all postoperative time periods compared to preoperative concentration (Friedman $P<.01)$. In addition, the concentrations at 6,12 , 


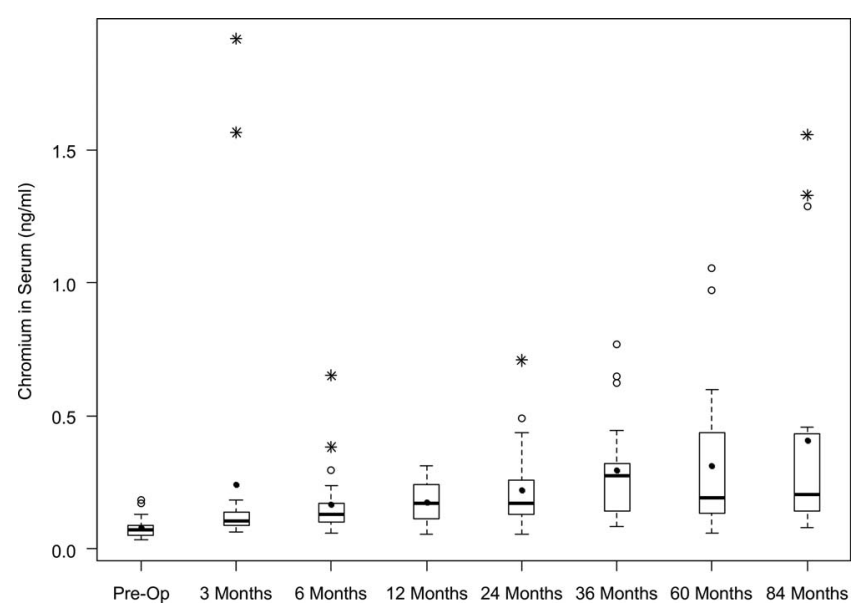

Figure 1. Cr serum metal concentrations. Solid line dividing the interquartile box represents the median and $(\bullet)$ represents the mean. Extended whiskers from each side of the box represent lowest and highest observations. Extreme cases $\left(^{*}\right)$ are defined as values more than 3 interquartile ranges from the upper or lower edge of the interquartile box, while outliers $\left({ }^{\circ}\right)$ are defined as cases with values between 1.5 and 3 interquartile ranges from the upper or lower edge of the box.

24, 36, 60, and 84 months were statistically higher than the 3-month concentrations (Friedman $P<$ .01 ); the concentrations at $12,36,60$, and 84 months were statistically higher than the 6-month concentrations (Friedman $P \leq .05$ ), and the concentration at 36 months was statistically higher than the $12-$ month concentration (Friedman $P<.05$ ). The concentrations at 60 and 84 months were not statistically different than what was observed at 36 months, which appeared to be the peak value.

Serum Ni concentrations were statistically higher at the 84-month postoperative time period than were preoperative concentrations (Friedman $P<$ .01 ) and statistically higher than the 3-, 12-, 24-, and 60 -month postoperative time periods (Friedman $P$ $<.03$ ). Additionally, the concentration at the 6month postoperative time period was higher than the 3-month postoperative time period (Friedman $P$ $<.02$ ), and the concentrations at the 36-month postoperative time period were statistically higher than those at the 3-and 12-month postoperative time periods (Friedman $P<.02$ ). Even for $\mathrm{Ni}$, the concentration appeared to peak at 36 months with no statistical difference when compared to concentrations at 60 and 84 months.

There were 7 subjects for $\mathrm{Cr}$ and 6 subjects for $\mathrm{Ni}$ that were identified as having either outlier or extreme concentrations at 1 or more time periods. (Subjects with values between 1.5 and 3 box lengths from the upper or lower edge of the box are defined as outliers. The box length is the interquartile range [25\%-75\%] [SPSS ver. 15.0]. Subjects with values

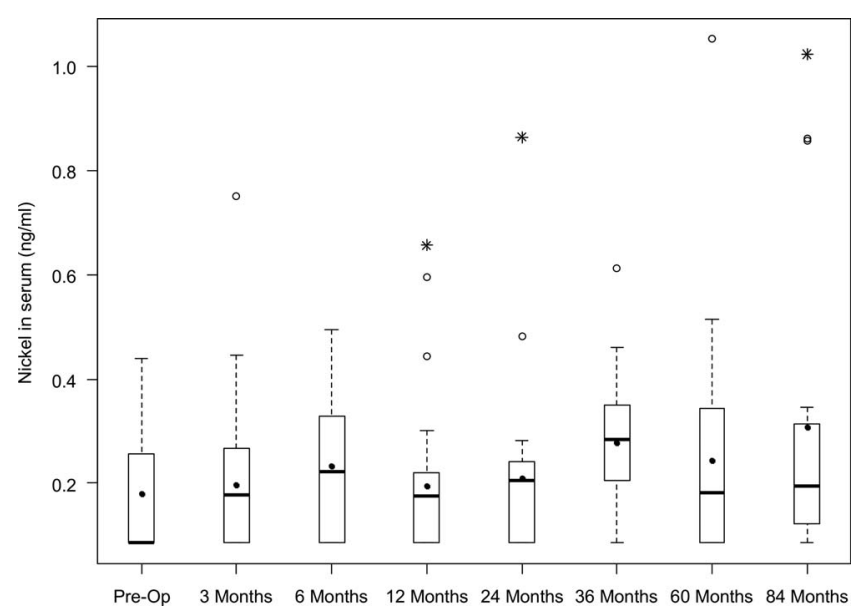

Figure 2. Ni serum metal concentrations. Solid line dividing the interquartile box represents the median and $(\bullet)$ represents the mean. Extended whiskers from each side of the box represent lowest and highest observations. Extreme cases $\left(^{*}\right)$ are defined as values more than 3 interquartile ranges from the upper or lower edge of the interquartile box, while outliers $\left(^{\circ}\right)$ are defined as cases with values between 1.5 and 3 interquartile ranges from the upper or lower edge of the box.

more than 3 box lengths from the upper or lower edge of the box are defined as extreme. The box length is the interquartile range $[25 \%-75 \%$ ] [SPSS ver. 15.0].)These included 4 common subjects that had both $\mathrm{Cr}$ and Ni outlier or extreme concentrations. Table 3 presents subjects with extreme and outlier concentrations at various time periods.

It is interesting to note that with an exception of 2 subjects (subject III at the 60-month postoperative period and VIII at the 84-month postoperative period in Table 3), the remaining subjects had $\mathrm{Ni}$ concentrations below the laboratory's normal reference range for $\mathrm{Ni}(<1 \mathrm{ng} / \mathrm{mL})$.

The detection limits for $\mathrm{Cr}$ and $\mathrm{Ni}$ were changed to 0.010 and $0.088 \mathrm{ng} / \mathrm{mL}$, respectively, at the 84 month testing cycle as a result of the improved sample handling and testing techniques introduced at this testing cycle. There were no undetectable $\mathrm{Cr}$ values in serum; hence, there was no impact on the reported $\mathrm{Cr}$ concentrations at 84 months due to this change. However, the lower detection limit resulted in 8 subjects having $\mathrm{Ni}$ concentrations higher than $0.085 \mathrm{ng} / \mathrm{mL}$ (the value which would have been assigned with the previous detection limit of $0.17 \mathrm{ng} /$ $\mathrm{mL}$ ) and therefore resulted in a higher median for the 84-month time period.

\section{DISCUSSION}

In this study, we looked at the long-term serum $\mathrm{Cr}$ and $\mathrm{Ni}$ concentrations for subjects implanted with stainless steel-based cervical disc replacement. 
Table 3. Subjects with statistically identified extreme and outlier concentrations at various time points (out, outlier; ext, extreme).

\begin{tabular}{|c|c|c|c|c|c|c|c|c|}
\hline Subject & Preoperative & 3 Мo & 6 Mo & 12 Mo & 24 Мо & $36 \mathrm{Mo}$ & 60 Mo & 84 Мo \\
\hline I & & & $\mathrm{Cr}_{\text {out }}$ & & $\begin{array}{l}\mathrm{Ni}_{\text {ext }} \\
\mathrm{Cr}_{\text {ext }}\end{array}$ & $\mathrm{Cr}_{\text {out }}$ & $\mathrm{Cr}_{\text {out }}$ & $\begin{array}{l}\mathrm{Ni}_{\text {out }} \\
\mathrm{Cr}_{\text {ext }}\end{array}$ \\
\hline $\begin{array}{l}\text { II } \\
\text { III }\end{array}$ & & & & $\mathrm{Ni}_{\text {out }}$ & $\mathrm{Ni}_{\text {out }}$ & $\begin{array}{l}\mathrm{Ni}_{\text {out }} \\
\mathrm{Cr}_{\text {out }}\end{array}$ & $\mathrm{Ni}_{\text {out }}$ & $\mathrm{Ni}_{\text {out }}$ \\
\hline IV & & $\mathrm{Cr}_{\text {ext }}$ & $\mathrm{Cr}_{\text {ext }}$ & & $\mathrm{Cr}_{\text {out }}$ & & $\mathrm{Cr}_{\text {out }}$ & $\mathrm{Cr}_{\mathrm{ext}}$ \\
\hline $\begin{array}{l}\text { V } \\
\text { VI }\end{array}$ & $\mathrm{Cr}_{\text {out }}$ & $\begin{array}{l}\mathrm{Ni}_{\text {out }} \\
\mathrm{Cr}_{\text {ext }}\end{array}$ & & $\mathrm{Ni}_{\text {out }}$ & & & & \\
\hline $\begin{array}{l}\text { VII } \\
\text { VIII }\end{array}$ & $\mathrm{Cr}_{\text {out }}$ & & & $\mathrm{Ni}_{\text {ext }}$ & & & & $\begin{array}{l}\mathrm{Ni}_{\text {ext }} \\
\mathrm{Cr}_{\text {out }}\end{array}$ \\
\hline IX & & & & & & $\mathrm{Cr}_{\text {out }}$ & & \\
\hline
\end{tabular}

The $\mathrm{Cr}$ concentrations at all time periods were statistically higher than the preoperative concentration, whereas the Ni concentration was statistically higher than the preoperative concentration only at 84 months. The $\mathrm{Cr}$ concentration continued to increase until 36 months, at which time it reached the steady state. Time periods after 36 months were not statistically different from the 36-month concentration. For $\mathrm{Ni}$, the highest concentration was observed at 36 months, and there was no statistical difference observed between the concentrations at 36 months and those at 60 and 84 months. The Ni concentration at 84 months was observed to be statistically higher than 60 months, but this was a result of change in the $\mathrm{Ni}$ detection limit at 84 months. These concentrations were still very low compared to the laboratory's normal reference range for $\mathrm{Ni}(<1 \mathrm{ng} / \mathrm{mL})$. The stabilization of concentrations observed after 36 months suggests a steady state where the 2 device components had accommodated each other and were generating metal concentrations at a constant rate.

The median serum $\mathrm{Cr}$ and $\mathrm{Ni}$ concentrations reported for the artificial cervical disc in the current study are lower than serum $\mathrm{Cr}$ and $\mathrm{Ni}$ concentrations reported in subjects with stainless steel implants for single- or multilevel posterior lumbar arthrodesis. Table 4 presents reported $\mathrm{Cr}$ and $\mathrm{Ni}$ concentrations for the stainless steel-based posterior instrumentation for adult and pediatric patient populations and for articulating metal-on-polyethylene and MOM hip joints. It is important to use caution when comparing serum metal concentrations in the current study with the reported values for spinal instruments and large joint arthroplasty, as the measurement of metal in blood or serum is a sensitive process and very susceptible to potential contaminations. It has been shown that variables such as analytic methodology, blood collection techniques, and time of collection can cause significant variation in the detection limits and subsequent results of a study measuring metal concentrations. $^{34-36}$ In addition, in large joint arthroplasty, CoCrMo alloy is utilized (not stainless steel), which differs in its $\mathrm{Cr}$ and $\mathrm{Ni}$ content from the stainless steel used in the disc arthroplasty of the present study and in the spinal instrumentation studies (Cr 27\%-30\%, Ni $<0.5 \%$ for CoCrMo alloy; $\mathrm{Cr} 17 \%-19 \%$, Ni $13 \%-15 \%$ for $316 \mathrm{~L}$ stainless steel).

There currently is no consensus on either the threshold level of metal concentrations in the blood at which adverse systemic effects begin appearing or the threshold concentration that should serve as a trigger for intervention. ${ }^{37}$ To assess the possible impact of serum metal concentrations on patients receiving the cervical disc replacement under study, an assessment of systemic adverse events in our study population was performed by chart review. Case histories were reviewed for systemic events reported during the period of device implantation. Those events were compared with systemic events previously reported in MOM hip implant literature. Some case reports and articles in the medical literature suggest that subjects with a MOM hip implant may be at risk for certain chronic metal ion toxicity syndromes (systemic reactions), including general hypersensitivity reaction (skin rash), cardiomyopathy, neurological changes including sensory changes (auditory or visual impairments), psychological status changes (including depression or cognitive impairment), renal function impairment, and thyroid dysfunction (including neck discomfort, fatigue, weight gain, or feeling cold). ${ }^{38,39}$ An evaluation of systemic events during cervical disc implantation with the device under study demon- 
Singh et al.

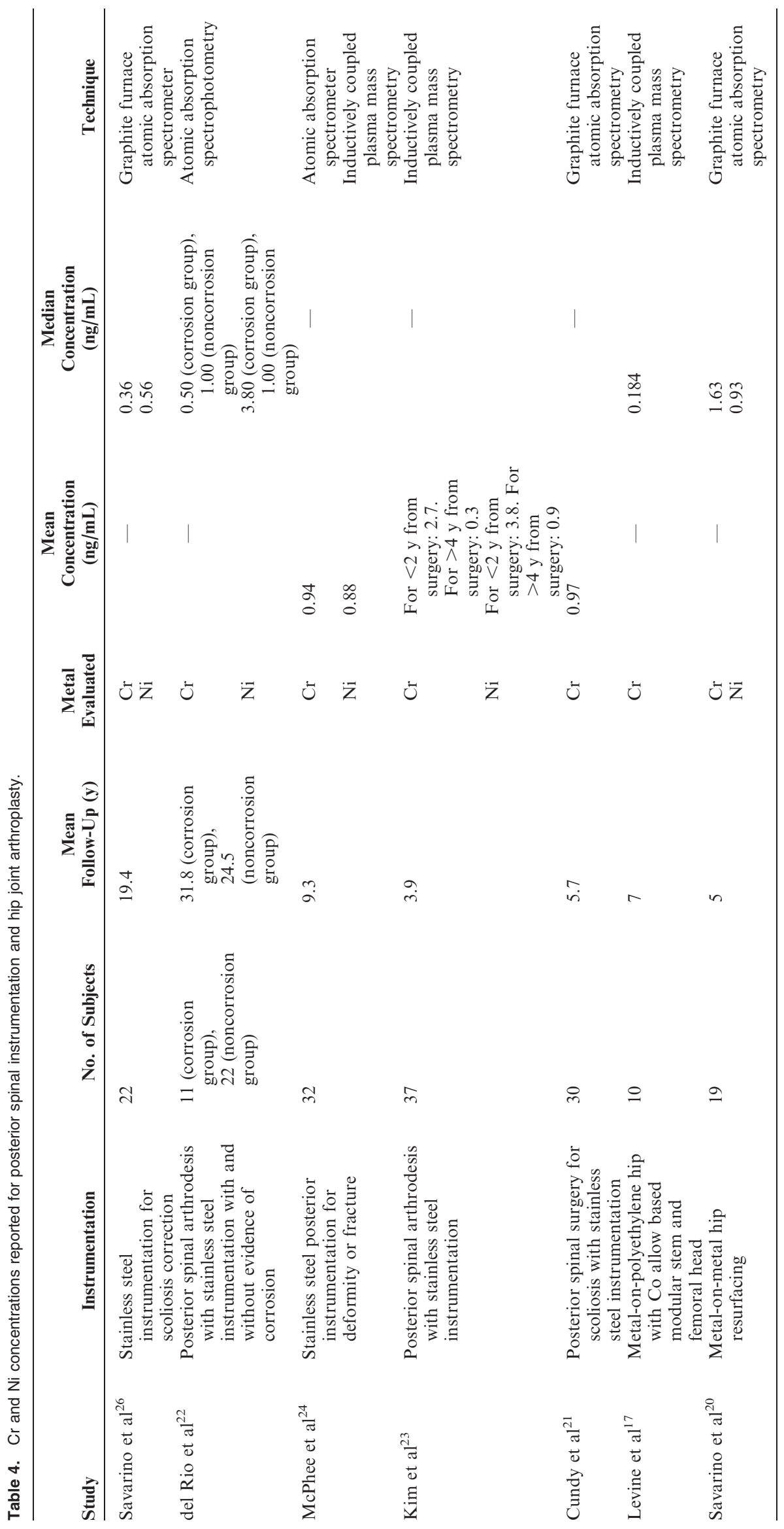


strated that there are no trending clinical symptoms or events suggestive of chronic metal toxicity syndrome in 335 study patients from the initial clinical study and the continued access arm. This chart review includes patients with explanted devices $(N=10)$ and patients with extreme or outlier concentrations in the present study $(N=9)$.

To evaluate the possible clinical implications of local debris, the case histories as well as the available histological data of the explanted patients $(8 / 10)$ were assessed. Histological examination of the explanted devices demonstrated absence of ALTR/osteolysis in the periprosthetic tissue. Additionally, the assessment of those patients' case histories suggested that device removal was most likely caused by patient or surgery-related factors, including traumatic events $(3 / 10)$, surgical technical causes (ie, inadequate decompression followed by early removal) (2/10), multiple work-related injuries $(1 / 10)$, or adjacent segment disease $(2 / 10)$. The combination of clinical data and histological analysis does not suggest that a biological reaction to local debris was the reason for device removal. It is important to mention that none of the explanted patients had serum metal concentration data, and therefore the correlation between histology and serum data was not feasible.

Local and systemic reactions to wear debris have been frequently reported in large joint implants. ${ }^{40,41}$ While reviewing the adverse events related to wear debris, it has been found that Co may be synergistic with $\mathrm{Cr}$ in eliciting adverse local and systemic reactions in large joint replacement patients. ${ }^{42-44}$ However, as noted above, the cervical disc arthroplasty in this study is made out of $316 \mathrm{~L}$ stainless steel, which does not include Co. Furthermore, none of the disc arthroplasty patients had systemic clinical symptoms or events suggestive of chronic metal toxicity.

This was a long-term prospective, longitudinal study presenting the $\mathrm{Cr}$ and $\mathrm{Ni}$ concentrations up to 84 months for the stainless steel-based MOM cervical disc arthroplasty. When compared with preoperative concentrations, higher serum $\mathrm{Cr}$ concentrations were detected at all postoperative time points, whereas Ni concentration only at 84 months was statistically higher than the preoperative concentration. The detected serum $\mathrm{Cr}$ and $\mathrm{Ni}$ concentrations were an order of magnitude lower than the concentrations reported for stainless steel-based posterior instrumentation without any signs of corrosion. A chart review revealed no clinical symptoms or events indicative of systemic metal toxicity in 335 study patients, including patients with explanted devices and patients with statistically identified extreme or outlier concentrations in the present study.

\section{REFERENCES}

1. Xie L, Liu M, Ding F, Li P, Ma D. Cervical disc arthroplasty (CDA) versus anterior cervical discectomy and fusion (ACDF) in symptomatic cervical degenerative disc diseases (CDDDs): an updated meta-analysis of prospective randomized controlled trials (RCTs). SpringerPlus. 2016;5(1):1188.

2. Zhang $\mathrm{Y}$, Liang $\mathrm{C}$, Tao $\mathrm{Y}$, et al. Cervical total disc replacement is superior to anterior cervical decompression and fusion: a meta-analysis of prospective randomized controlled trials. PloS One. 2015;10(3):e0117826.

3. Botelho RV, Moraes OJ, Fernandes GA, Buscariolli Ydos S, Bernardo WM. A systematic review of randomized trials on the effect of cervical disc arthroplasty on reducing adjacent-level degeneration. Neurosurg Focus. 2010;28(6):E5.

4. Gao Y, Liu M, Li T, Huang F, Tang T, Xiang Z. A metaanalysis comparing the results of cervical disc arthroplasty with anterior cervical discectomy and fusion (ACDF) for the treatment of symptomatic cervical disc disease. J Bone Joint Surg Am. 2013;95(6):555-561.

5. Kasliwal MK, Traynelis VC. Motion preservation in cervical spine: review. J Neurol Sci. 2012;56(1):13-25.

6. Rao MJ, Nie SP, Xiao BW, Zhang GH, Gan XR, Cao SS. Cervical disc arthroplasty versus anterior cervical discectomy and fusion for treatment of symptomatic cervical disc disease: a meta-analysis of randomized controlled trials. Arch Orthop Trauma Surg. 2015;135(1):19-28.

7. McAfee PC. The indications for lumbar and cervical disc replacement. Spine J. 2004;4(suppl 6):177S-181S.

8. Bozic KJ, Ries MD. Wear and osteolysis in total hip arthroplasty. Semin Arthroplasty. 2005;16(2):142-152.

9. Langton DJ, Jameson SS, Joyce TJ, Hallab NJ, Natu S, Nargol AV. Early failure of metal-on-metal bearings in hip resurfacing and large-diameter total hip replacement: a consequence of excess wear. J Bone Joint Surg Br. 2010;92(1):38-46.

10. Sansone V, Pagani D, Melato M. The effects on bone cells of metal ions released from orthopaedic implants. A review. Clin Cases Miner Bone Metab. 2013;10(1):34-40.

11. Smith J, Lee D, Bali K, et al. Does bearing size influence metal ion levels in large-head metal-on-metal total hip arthroplasty? A comparison of three total hip systems. J Orthop Surg Res. 2014;9:3.

12. Burkus JK, Traynelis VC, Haid RW Jr, Mummaneni PV. Clinical and radiographic analysis of an artificial cervical disc: 7-year follow-up from the Prestige prospective randomized controlled clinical trial: clinical article. J Neurosurg Spine. 2014;21(4):516-528.

13. Golish SR, Anderson PA. Bearing surfaces for total disc arthroplasty: metal-on-metal versus metal-on-polyethylene and other biomaterials. Spine J. 2012;12(8):693-701. 
14. Kolatat K, Perino G, Wilner G, et al. Adverse local tissue reaction (ALTR) associated with corrosion products in metal-on-metal and dual modular neck total hip replacements is associated with upregulation of interferon gamma-mediated chemokine signaling. J Orthop Res. 2015;33(1):1487-1497.

15. Kurtz SM, Ciccarelli L, Harper ML, Siskey R, Shorez J, Chan FW. Comparison of in vivo and simulator-retrieved metal-on-metal cervical disc replacements. Int J Spine Surg. 2012;6:145-156.

16. Paukkeri EL, Korhonen R, Hamalainen M, et al. The inflammatory phenotype in failed metal-on-metal hip arthroplasty correlates with blood metalconcentrations. PloS One. 2016;11(5):e0155121.

17. Levine BR, Hsu AR, Skipor AK, et al. Ten-year outcome of serum metal ion levels after primary total hip arthroplasty: a concise follow-up of a previous report. $J$ Bone Joint Surg Am. 2013;95(6):512-518.

18. Omlor GW, Kretzer JP, Reinders J, et al. In vivo serum titanium ion levels following modular neck total hip arthroplasty-10 year results in 67 patients. Acta Biomter. 2013;9(4):6278-6282.

19. Sarmiento-Gonzalez A, Marchante-Gayon JM, TejerinaLobo JM, Paz-Jimenez J, Sanz-Medel A. High-resolution ICPMS determination of $\mathrm{Ti}, \mathrm{V}, \mathrm{Cr}, \mathrm{Co}, \mathrm{Ni}$, and $\mathrm{Mo}$ in human blood and urine of patients implanted with a hip or knee prosthesis. Anal Bioanal Chem. 2008;391(7):2583-2589.

20. Savarino L, Cadossi M, Chiarello E, et al. How do metal ion levels change over time in hip resurfacing patients? A cohort study. Sci World J. 2014;2014:7.

21. Cundy TP, Delaney CL, Rackham MD, et al. Chromium ion release from stainless steel pediatric scoliosis instrumentation. Spine (Phila Pa 1976). 2010;35(9):967-974.

22. del Rio J, Beguiristain J, Duart J. Metal levels in corrosion of spinal implants. Eur Spine J. 2007;16(7):10551061.

23. Kim YJ, Kassab F, Berven SH, et al. Serum levels of nickel and chromium after instrumented posterior spinal arthrodesis. Spine (Phila Pa 1976). 2005;30(8):923-926.

24. McPhee IB, Swanson CE. Metal ion levels in patients with stainless steel spinal instrumentation. Spine (Phila $\mathrm{Pa}$ 1976). 2007;32(18):1963-1968.

25. Rackham MD, Cundy TP, Antoniou G, Freeman BJ, Sutherland LM, Cundy PJ. Predictors of serum chromium levels after stainless steel posterior spinal instrumentation for adolescent idiopathic scoliosis. Spine (Phila Pa 1976). 2010;35(9):975-982.

26. Savarino L, Greggi T, Martikos K, Lolli F, Greco M, Baldini N. Long-term systemic metal distribution in patients with stainless steel spinal instrumentation: a case-control study. J Spinal Disord Tech. 2015;28(3):114-118.

27. Villarraga ML, Cripton PA, Teti SD, et al. Wear and corrosion in retrieved thoracolumbar posterior internal fixation. Spine (Phila Pa 1976). 2006;31(21):2454-2462.

28. Harper ML, Dooris A, Paré PE. The fundamentals of biotribology and its application to spine arthroplasty. $S A S J$. 2009;3(4):125-132.

29. Amstutz HC, Campbell PA, Dorey FJ, Johnson AJ, Skipor AK, Jacobs JJ. Do ion concentrations after metal-onmetal hip resurfacing increase over time? A prospective study. $J$ Arthroplasty. 2013;28(4):695-700.

30. Hsu AR, Levine BR, Skipor AK, Hallab NJ, Paprosky
WG, Jacobs JJ. Effect of a second joint arthroplasty on metal ion levels after primary total hip arthroplasty. Am J Orthop (Belle Mead, N.J.). 2013;42(10):E84-E87.

31. Jacobs JJ, Skipor AK, Black J, Urban R, Galante JO. Release and excretion of metal in patients who have a total hipreplacement component made of titanium-base alloy. $J$ Bone Joint Surg Am. 1991;73(10):1475-1486.

32. Novak CC, Hsu AR, Della Valle CJ, et al. Metal ion levels in maternal and placental blood after metal-on-metal total hip arthroplasty. Am J Orthop (Belle Mead, N.J.). 2014:43(12):E304-E308.

33. Skipor AK, Campbell PA, Patterson LM, Anstutz HC, Schmalzried TP, Jacobs JJ. Serum and urine metal levels in patients with metal-on-metal surface arthroplasty. J Mater Sci Mater Med. 2002;13(12):1227-1234.

34. Keegan GM, Learmonth ID, Case CP. Orthopaedic metals and their potential toxicity in the arthroplasty patient: a review of current knowledge and future strategies. $J$ Bone Joint Surg Br. 2007;89(5):567-573.

35. MacDonald SJ, Brodner W, Jacobs JJ. A consensus paper on metal ions in metal-on-metal hip arthroplasties. $J$ Arthroplasty. 2004;19(8 suppl 3):12-16.

36. Zeager M, Woolf AD, Goldman RH. Wide variation in reference values for aluminum levels in children. Pediatrics. 2012;129(1):e142-e147.

37. US Food and Drug Administration. Information for orthopaedic surgeons. 2015. https:/www.fda.gov/Medical Devices/ProductsandMedicalProcedures/Implantsand Prosthetics/MetalonMetalHipImplants/ucm241667.htm. Accessed May 15, 2017.

38. US Food and Drug Administration. Concerns about Metal-on-Metal Hip Implants. 2015. https://www.fda.gov/ MedicalDevices/ProductsandMedicalProcedures/Im plantsandProsthetics/Metalon MetalHipImplants $\% 20$ ucm241604.htm. Accessed May 15, 2017.

39. Stanton T. Metal-on-metal hip implants: the clinical issues. 2012. https://www.aaos.org/aaosnow/2012/may/clinical/ clinical4. Accessed January 25, 2017.

40. Bozic KJ, Browne J, Dangles CJ, et al. Modern metalon-metal hip implants. J Am Acad Orthp Surg. 2012;20(6):402406.

41. Ladon D, Doherty A, Newson R, Turner J, Bhamra M, Case CP. Changes in metal levels and chromosome aberrations in the peripheral blood of patients after metal-on-metal hip arthroplasty. J Arthroplasty. 2004;19(8 suppl 3):78-83.

42. Bradberry SM, Wilkinson JM, Ferner RE. Systemic toxicity related to metal hip prostheses. Clin Toxicol. 2014;52(8):837-847.

43. Cheung AC, Banerjee S, Cherian JJ, et al. Systemic cobalt toxicity from total hip arthroplasties: review of a rare condition part 1-history, mechanism, measurements, and pathophysiology. Bone Joint J. 2016;98-B(1):6-13.

44. Zywiel MG, Cherian JJ, Banerjee S, et al. Systemic cobalt toxicity from total hip arthroplasties: review of a rare condition part 2. measurement, risk factors, and step-wise approach to treatment. Bone Joint J. 2016;98-B(1):14-20.

Disclosures and COI: Vaneet Singh and Abdulhafez A. Selim are employees of Medtronic, Inc. Joshua J. Jacobs received research grant from 
Medtronic, Inc., to conduct this metal concentration work. Dr. Jacobs was also a paid consultant for Medtronic Corporation during the time of this study. For the remaining authors, none were declared. This study was funded by Medtronic, Inc. This study was conducted under a US Food and Drug Administration-approved investigational device exemption (G010188) and was approved by the institutional review board of each participating site, and all participants signed an informed consent prior to their inclusion in the study.
Corresponding Author: Vaneet Singh, MS, MBA, Medtronic, Inc., 2600 Sofamor Danek Drive, Memphis, TN 38132. Phone : (901) 399-2856; Fax (901)399-2038; Email: vaneet.singh@medtronic.com.

Published 31 August 2018

This manuscript is generously published free of charge by ISASS, the International Society for the Advancement of Spine Surgery. Copyright (C) 2018 ISASS. To see more or order reprints or permissions, see http://ijssurgery.com. 